\title{
ANTICIPATING AND MANAGING THE PSYCHOLOGICAL COST OF CIVIL LITIGATION
}

\author{
MICHAELA KEET \\ HEATHER HEAVIN \\ SHAWNA SPARROW*
}

Despite growing national attention on the costs of accessing justice, surprisingly little information has been collected about the psychological 'costs' of engaging in litigation. This article summarizes the health and psychology literature, to present a picture of the impact that litigation can have on litigants' health, state of mind, life goals and social relationships. Set against professional obligations embedded in the lawyer's role, we assert that awareness of the negative impacts of legal processes on the emotional and psychological functioning of clients is important. With greater awareness, lawyers can better assess the value of litigation, prepare their clients (and themselves) for litigation stress, and, where appropriate, take preventative actions to minimize the negative aspects of the litigation experience. With that in mind, we identify positive solution-oriented responses to preventing, reducing and alleviating litigation stress. These strategies focus on client-centred communication, supports and planning.

Malgré l'intérêt grandissant que suscitent à l'échelle nationale les coûts liés à l'accès à la justice, il est étonnant de voir que peu de renseignements ont été recueillis au sujet des coûts "psychologiques" découlant de la décision d'engager des poursuites. Dans cet article, nous résumons la littérature des domaines de la santé et de la psychologie afin de brosser un tableau des répercussions que les litiges peuvent avoir sur la santé, l'état d'esprit, les objectifs de vie et les relations sociales des parties. À notre avis, eu égard aux obligations professionnelles inhérentes au rôle de l'avocat, il est important que celui-ci soit conscient des répercussions défavorables des poursuites en justice sur le bien-être émotif et psychologique de ses clients. S’ils sont mieux sensibilisés à ces répercussions, les avocats seront davantage en mesure de déterminer la valeur des litiges, de préparer leurs clients (et eux-mêmes) au stress lié aux poursuites et, dans les cas opportuns, de prendre des mesures préventives pour minimiser les aspects défavorables de l'expérience du litige. C'est avec cette réalité à l'esprit que nous proposons des pistes de solution de nature à éliminer ou, à tout le moins, à réduire le stress lié aux litiges. Ces stratégies mettent l'accent sur la communication, le soutien et la planification axés sur le client.

\section{INTRODUCTION}

The direct financial cost of civil litigation - and how that impacts individuals and social systems - has dominated the access to justice policy agenda for the last several years. Legal fees and administrative costs associated with suing or being sued are viewed as creating a 'gateway barrier' for justice-seekers. Until very recently, studies on the costs of civil litigation have therefore centred on these actual legal 
costs and direct financial outcomes, with less consideration for the social and psychological dimensions of the process. ${ }^{1}$ In Canada, that is beginning to change with the Costs of Justice Project's exploration of the multi-faceted effects of unresolved legal conflict and the National Self-Represented Litigants Project's collection of personal experiences with the justice system. ${ }^{2}$ We already know that the litigation environment can cause chronic stress for lawyers. ${ }^{3}$ Still, the litigant's experience - "the full extent to which litigation is stressful and what factors of litigation exacerbate or mediate psychological symptoms" - has not been well studied. ${ }^{4}$ The health and psychology literature offers a starting point for better understanding such consequences.

Raising awareness within the legal profession of litigation's psychological impact opens up questions about professional responsibility and ethical lawyering. While lawyers are not bound to a 'do no harm's

* Professors Keet and Heavin are on faculty at the College of Law, University of Saskatchewan, and have published numerous articles on the topic of litigation risk analysis. Both were involved in the establishment of CREATE Justice, a centre for research into access to justice and dispute resolution issues. Shawna Sparrow is a law student at the University of Saskatchewan, with a background in Education. The authors would also like to acknowledge the research assistance provided by Cheryl Giesbrecht, and the guidance offered by our colleague in the Department of Psychology, Dr. Melanie Morrison.

1 The first large-scale empirical study of litigation costs in North America (a multi-State 1980s study) did try to assess the parties' observations about the economics of their litigation (the overall impact of the gains and costs) without detailing what those might have been; see David M Trubek et al, "The Costs of Ordinary Litigation" (October 1983) 31:1 UCLA L Rev 72 at 119-120. Trubek acknowledged this limitation: "[O]ur analysis cannot measure non-monetary 'internal' effects..." at 119-120.

2 See Canadian Forum on Civil Justice, "Costs of Justice Project" online: $<$ http://www.cfcj-fcjc.org/cost-of-justice $>$. See Julie McFarlane, "The National Self-Represented Litigants Project: Identifying and Meeting the Needs of SelfRepresented Litigants" [NSRLS] (May 2013), online: <representingyourselfcanada.files.wordpress.com/2014/05/nsrlpsrl-research-study-final-report.pdf $>$. See Noel Semple, "The Cost of Seeking Civil Justice in Canada" (2016) 93:3 Can Bar Rev 639, which extracts examples of negative feelings described by self-represented litigants in interviews conducted for the NSRLS study; Reported feelings about interactions within the justice system, including with legal professionals included "humiliated", "stressed", "bullied", "frustrated", "afraid", "traumatized", and others - with the most common response being "overwhelmed" at 666. See also see the legal health checks referenced in: Canadian Bar Association, "Promoting Preventative Legal Health: A Tool Kit for Lawyers", online:

$<$ http://www.cba.org/CBAMediaLibrary/cba_na/PDFs/CBA\%20Equal\%20Justice/Preventive-Health-Toolkit-eng.pdf>; Canadian Bar Assocaition, Legal Health Checks, online: <http://www.cba.org/CBA-Equal-Justice/Resources/LegalHealth-Checks>.

3 Dennis Portnoy, "Burnout and Compassion Fatigue: Watch for Signs" (2011) 92 Health Prog 47 at 48; Lee Norton, Jennifer Johnson \& George W Woods, "Burnout and Compassion Fatigue: What Lawyers Need to Know" (2015-2016) 84 UMKC L Rev 987 at 989; Lisa Morgillo, "Do Not Make Their Trauma Your Trauma: Coping with Burnout as a Family Law Attorney" (2015) 53 Fam Ct Rev 456 at 457; John Hagan \& Fiona Kay, "Even Lawyers Get the Blues: Gender, Depression, and Job Satisfaction in Legal Practice" (2007) 41 Law \& Soc'y Rev 51 at 69.

4 C Diesen \& H Koch, "Contemporary $21^{\text {st }}$ Century Therapeutic Jurisprudence in Civil Cases: Building Bridges Between Law and Psychology" (2016) 2:1 Ethics, Medicine and Public Health 13 at 23. The lack of research about the psychological impact of litigation has been called an "intellectual void"; Jamie O'Connell, "Gambling with the Psyche: Does Prosecuting Human Rights Violators Console Their Victims?” (2005) 46 Harv Intl LJ 295 at 299.

5 The World Medical Association (WMA) International Code of Medical Ethics articulates duties of Physicians to Patients to include acting "in the patient's best interest when providing medical care." Online: <https://www.wma.net/policiespost/wma-international-code-of-medical-ethics/>; The Canadian Medical Association (CMA) Code of Ethics (2004) identifies Fundamental Responsibilities of Physicians, the first of which is to "1. Consider the well-being of the patient: 
principle, Codes of Conduct require lawyers to consider the interests of their clients by holding them to standards of competency and quality, including requiring lawyers to provide honest and candid advice and information to clients. ${ }^{6}$ As a result, awareness of the negative impacts of legal processes on the emotional and psychological functioning of clients is important. With greater awareness, lawyers can better prepare their clients for litigation stress, and, where appropriate, take preventative actions to minimize the negative aspects of the litigation experience. Within a larger frame, this article provides an impetus for the profession to 'do better' in designing and developing processes with the end-user in mind. ${ }^{7}$ If the processes utilized to resolve conflict compromise the well-being of participants, then we must seek out better process solutions and supports: The protective value of law must not be outweighed by the psychological or emotional expense of enforcing such rights. ${ }^{8}$ We recognize that unresolved conflict is also stress-inducing, and that the ability to access legal processes can also have beneficial emotional and psychological impacts, distinct from the financial outcomes. ${ }^{9}$

In this article, our initial starting point is to acknowledge the litigation stress experienced by individuals engaged with the civil justice system. We then identify the types of claims or proceedings where certain types of physical, social and psychological impacts have been observed, documented or

online $<$ https://www.cma.ca/Assets/assetslibrary/document/en/advocacy/policyresearch/CMA_Policy_Code_of_ethics_of_the_Canadian_Medical_Association_Update_2004_PD04-06-e.pdf $>$; the American Medical Association


patient, including requiring the physician to be "dedicated to providing competent medical care, with compassion and respect for human dignity and rights" and "while caring for the patient, regard responsibility to the patient as paramount". online: < https://www.ama-assn.org/sites/default/files/media-browser/principles-of-medical-ethics.pdf>.

6 Federation of Law Societies of Canada, Model Code of Professional Conduct (2017) (sets standards for competency, quality and candour (see r 3.1-2, commentary 1-15; r 3.2-1, commentary 1-6; r 3.2-2, and obligates lawyers to "advise and encourage a client to compromise or settle a dispute whenever it is possible to do so on a reasonable", r 3.2-4). Online <http://flsc.ca/wp-content/uploads/2014/10/Model-Code-as-amended-March-2017-Final.pdf> [Model Code].

7 At the Innovation Roundtable: “Tools of Innovation" hosted by the Action Committee on Access to Justice in Civil and Family Matters and CIAJ (Vancouver, BC, 22 March 2017), workshop sessions on "Using Design Thinking in the Justice System" and "Using Lean and Continuous Improvement in the Justice System" provided examples of how legal processes are being developed or improved upon when a 'human centric/end user' approach is adopted. Online: $<$ https://ciaj-icaj.ca/wp-content/uploads/events/2017/01/tools-of-innovation-program.pdf $>$. The introduction of British Columbia's on-line Civil Resolution Tribunal handles both condominium/strata and small claims (under \$5000) disputes is a recent example of how the justice system has applied user-design thinking in adopting new processes that minimize both costs and stress associated with litigation processes. See online: $<$ https://civilresolutionbc.ca/.> Jean Sorensen, "Civil Resolution Tribunal set to launch small claims dispute tool" (7 February 2017) Legal Feeds (blog), online: $<$ http://www.canadianlawyermag.com/legalfeeds/3668/civil-resolution-tribunal-set-to-launch-small-claims-disputetool.html>.

8 Model Code, supra note 6, r 5.6-1 further provides that "A lawyer must encourage public respect for and try to improve the administration of justice." Commentary 2 accompanying this rule further suggests that "constant effort must be made to improve the administration of justice and thereby, to maintain public respect for it."

9 Martin Gramatikov, "A Framework For Measuring the Costs of Paths to Justice" (February 2009) 2 J Juris 111 at 145 identifies benefits such as happiness, relief, confidence and triumph. Semple, supra note 2 at 667, 668 reviewed interview transcripts with self-represented litigants concluding that approximately $20 \%$ of the reported feelings (about process) were positive. See also benefits listed in Alan M Goldstein, ed, Handbook of Psychology, Forensic Psychology, vol 11 (New Jersey: Wiley, 2003) ch 28. 
studied. ${ }^{10} \mathrm{~A}$ third and critical goal of this paper it to provide the reader with further information about how litigation stress may manifest in other social and psychological forms, including: anxiety, emotional and relationship difficulties, impaired memory function and neurosis. While the literature primarily focuses on the individual client experience, we also touch upon community impacts, as well as impacts experienced by lawyers themselves. How certain steps in the traditional litigation process can cause and exacerbate stress is the focus of the fourth section of this paper. Attention to procedural impacts is important as the fifth part of the article identifies positive solution-oriented responses to prevent, reduce and alleviate litigation stress. These strategies focus on client-centred communication, supports and planning. On the assumption that this is an issue of pressing concern, and one that needs significantly more attention in law schools, sites of legal practice, and policy-makers' boardrooms, we conclude with suggestions for further study and research aimed at examining and improving the experience of litigants and their lawyers.

\section{WHAT IS LITIGATION STRESS?}

It is clear that people can and do respond to a legal process in a way that is distinct from its outcome. ${ }^{11}$ Although a legal process itself can have therapeutic benefits, ${ }^{12}$ the more common documented impact is harm - emotional and psychological harm. ${ }^{13}$ It has been argued that precise terminology is needed to describe emotional harms resulting from the legal process and that these harms

10 It is important to first acknowledge the incomplete nature of this information base. A number of the more thoughtful articles offer conceptual frameworks for understanding litigation-generated psychological distress, but are primarily analytical and theoretical - not data- or evidence-based. Experts in the field of psychology have consistently noted the dearth of in-depth empirical data on litigation-generated psychological consequences. The articles which do present study results cover a wide range of methodologies: some are interview-based and some survey-based; some targeted litigants and others legal and counseling professionals; some reviewed only medical files and other documents; many are specific to specialized kinds of civil litigation. This paper draws from many articles and reports, with the following summative limitations. Aside from the development we have noted above, very little has been done in Canada - and the research from the American context (with its distinct litigation culture) may not translate easily.

11 E Allan Lind et al, "In the Eye of the Beholder: Tort Litigants' Evaluations of Their Experiences in the Civil Justice System” (1990) 24 Law \& Soc’y Rev 953 at 957.

12 Supra note 9.

13 See e.g. Gary Fulcher, "Litigation-induced Trauma Sensitisation (LITS) - A Potential Negative Outcome of the Process of Litigation" (2004) 11 Psychiatry Psychol \& L 79 at 80; Judy Gutman et al, "The psychological impact of the legal system of sexually abused children" (2001) 8 Psychiatry, Psychol \& Law 174-179; Paul Elston, Ron Bracey \& Hugh Koch, "Litigation stress" (2006) 150:34 The Solicitor's Journal 1146; RL Binder, MR Trimble \& DE McNiel, "Is money a cure? Follow-up litigants in England" (1991) 19 Bull Am Acad Psychiatry Law 151-160 and Edward J Hickling, Edward B Blanchard \& Matthew T Hickling, "The Psychological Impact of Litigation: Compensation Neurosis, Malingering, PTSD, Secondary Traumatization, and Other Lessons from MVAS” (2006) 55 DePaul L Rev 617 at 625. Nicole Zapzalka found that litigants who had previously involved in a courtroom trial had higher perceived anxiety than those previously involved in an alternative dispute resolution; Nicole M Zapzalka, The Psychological Impact of Civil Litigation: A Comparison of Perceived Anxiety Levels in Civil Litigation as Viewed by Trial and Alternative Dispute Resolution Litigants (PhD dissertation, Capella University, 2007) [unpublished] at 75. 
are widely recognized yet are treated as invisible inside the legal process. ${ }^{14}$ Psychologists offer several labels, without consensus. "Critogenic (law-caused) harm" is described as the "intrinsic and often inescapable harms caused by the litigation process itself, even when the process is working exactly as it should." "Litigation-response syndrome" is "made up of complaints that arise solely from the experience of being personally involved in a lawsuit, rather than the events that precipitated the litigation."16 Finally, the general burden of stress accompanying litigation has been called "forensic stress," 17 which in some individuals develops into "forensic stress disorder."18

From the perspective of some psychologists, this type of stress warrants its own diagnostic category. Litigation-generated stress is, on some levels, voluntary: litigants opt-in. ${ }^{19}$ Litigation stress is also unique in that its impact is temporary, whereas other stress disorders can continue indefinitely. Stress can begin as early as the first notification that one is going to be sued ${ }^{20}$ and lasts until well after litigation has ended. ${ }^{21}$ Most importantly, it intensifies at critical stages or "psychological soft spots" in the litigation process: ${ }^{22}$ important examinations or questioning, independent evaluations, pivotal hearings and the trial itself. ${ }^{23}$

Empirical research raises the alarm about psychological impact, but is not conclusive, in part because of the difficulty of distinguishing between the strain caused by the original loss and that caused by the process. ${ }^{24}$ The research is also constrained by its limited focuses on particular types of claims, such as worker's compensation or motor vehicle accident cases. Here, research historically suggests a correlation between continued litigation, stress, injury and symptomatic complaints, and concern about "litigation neurosis" (or, in insurance vernacular, "malingering") has long influenced the management of

14 Thomas G Gutheil et al, "Preventing 'critogenic' harms: minimizing emotional injury from civil litigation” (2000) $28 \mathrm{~J}$ Psychiatry \& L 5 at 6.

15 Ibid.

16 Paul R Lees-Haley, "Litigation Response Syndrome: How Stress Confuses the Issues" (1989) 56 Def Counsel J 110 at 110.

17 Cohen argues that forensic stress warrants its own diagnostic category, given that it is distinct from other types of stress; Larry J Cohen \& Joyce H Vesper, "Forensic Stress Disorder" (2001) 25 Law \& Psychol Rev 1 at 4.

18 Ibid.

19 Ibid. This observation is tempered by the fact that once a litigation process is started, parties on either side (although particularly defendants) will be required to engage and respond.

20 Lees-Haley, supra note 16 at 114. Or, for Plaintiffs, stress complaints may arise as soon as they consider embarking on litigation. Ibid. Overall, there appears to be no difference in anxiety levels between plaintiffs and defendants; Zapzalka, supra note 13 at 69 .

21 Cohen maintains that most symptoms of forensic stress diminish within six months after litigation has concluded, while Paul Haley-Lees pegs recovery taking place over a course of weeks or days. Cohen \& Vesper, supra note 17 at 4; LeesHaley, supra note 16 at 114. Even after the case has concluded, unpleasant memories from the litigation experience can continue to result in stress: J Steven Picou, "Disaster, Litigation, and the Corrosive Community" (2003-2004) 82 Soc F 1493 [Picou, "Corrosive Community"] at 1503.

22 Captain Evan R Seamone, “The Veterans' Lawyer as Counselor: Using Therapeutic Jurisprudence to Enhance Client Counseling for Combat Veterans with Posttraumatic Stress Disorder" (2009) 202 Mil L Rev 185 at 195; Bruce Winick, “Therapeutic Jurisprudence and the Role of Counsel in Litigation" (2000-2001) 37 Cal W L Rev 105 at 110.

23 Lees-Haley, supra note 16 at 114.

24 Larry H Strasburger, "The Litigant-Patient: Mental Health Consequences of Civil Litigation" (1999) 27:2 J Am Acad Psychiatry Law 203 at 203. 
WCB and MVA cases. ${ }^{25}$ Some attempts have been made, more recently, to broaden the scope of the research to civil litigants, more generally. In 2007, Zapzalka administered questionnaires to plaintiffs and defendants recently involved in legal processes in Minneapolis, to measure anxiety responses to hypothetical scenarios. ${ }^{26}$ The data suggests that those previously involved in a courtroom trial had higher perceived anxiety than those previously involved in an alternative dispute resolution. ${ }^{27}$ In sum, an "intellectual void" 28 surrounding the relationship between litigation and psychological health has been acknowledged, but research and theories presented over the past two decades do begin to paint the following picture.

\section{WHERE IS LITIGATION STRESS EXPERIENCED MORE ACUTELY?}

Although levels may vary according to personality type and personal circumstances, psychological stress has been described as inevitable for all clients ${ }^{29}$ - in any lawsuit in which the stakes feel significant to the litigant. ${ }^{30}$ Some personality types are more vulnerable to litigation stress than others, and the pressure of litigation can even activate certain personality predispositions. Individuals who have been involved in pre-litigation trauma (such as accidents) or who have PTSD may experience more intense physical manifestations of anxiety. Other capacity issues or prior experiences may also intensify the impact and counteract the restorative potential of litigation, for example, for people who are braininjured or suffer with pain disorders and other chronic or debilitating physical conditions. Certain kinds of cases - civil sexual assault actions and sexual harassment claims, for example - may predispose claimants to higher levels of anxiety and psychological risk, competing with therapeutic benefits. We have organized the research into the following categories.

\section{A. Claims Involving People with Cognitive, Mental or Emotional Vulnerabilities}

Some personality types are more vulnerable to litigation stress than others, and it is said that the pressure of litigation can even activate certain personality predispositions. ${ }^{31}$ Litigation can be extremely challenging for people with control issues, who may react by becoming paranoid, angry and argumentative, or pre-occupied with the case to the exclusion of any other activity. ${ }^{32}$ People with certain personality types blame others for difficulties arising from what may be their own poor communication. ${ }^{33}$ This problem can be further disturbed by litigation stress. ${ }^{34}$ According to Lees-

25 Hickling et al, supra note 13 at 625; Elston, Bracy \& Koch, supra note 13 at 1146; Binder et al, supra note 13 at 151 . See also Fulcher, supra note 13 at 80.

26 Zapzalka, supra note 13.

27 Ibid at 75.

28 O'Connell, supra note 4 at 299.

29 Strasburger, supra note 24 at 204.

30 Lees-Haley, supra note 16 at 112.

31 Herbert N Weissman, "Distortions and Deceptions in Self Presentation: Effects of Protracted Litigation in Personal Injury Cases" (1990) 8 Behav Sci \& Law 67 at 68. It should also be noted that certain dispositions can also mitigate litigation stress: optimism and endurance. See e.g. John P Gould, "The economics of legal conflicts" (1973) 2 J Leg Stud 279 at 297.

32 Cohen \& Vesper, supra note 17 at 15.

33 Lees-Haley, supra note 16 at 111.

34 Ibid. 
Haley, litigants already predisposed to stress, mood disorders, anxiety disorders or substance abuse problems - and their close relatives - may be especially vulnerable to litigation stress. ${ }^{35}$ It is also posited that people with dependent personalities may experience more acute problems with litigation stress. ${ }^{36}$ As these clients may over-rely on their attorneys for care and support, they can eventually become overwrought, and exhibit symptoms of panic attacks, heart palpitations and gastrointestinal problems. ${ }^{37}$ When dealing with such a client, lawyers feel pressured to assume roles they are neither trained nor qualified to fill. ${ }^{38}$

Individuals who witnessed a violent or life-threatening event prior to litigation may also experience acute levels of anxiety. ${ }^{39}$ Clients suffering from PTSD are often already embroiled in the psychological defence of avoidance. For PTSD patients involved in litigation, this defence becomes thwarted as they become obligated to revisit the trauma through interviews, examinations and testimony. ${ }^{40}$ As the avoidance defence fails, these litigants experience a resurgence of traumatic reactions. ${ }^{41}$ Military veteran clients often fall into this category as they experience high rates of PTSD related to their combat experiences - and the high suicide attempt rate of veterans underscores the need for lawyers to be aware of psychological soft spots when working with these clients. ${ }^{42}$

Traumatic brain injury often appears alongside PTSD and can influence a client's judgment, as well as adversely affect the attorney-client relationship. ${ }^{43}$ In a study involving individuals recovering from a mild brain injury, it was found that those who pursued litigation were significantly more likely to exhibit anxiety, depression and social dysfunction. ${ }^{44}$ They also experienced more physical symptoms such as headaches and dizziness than those who did not litigate. ${ }^{45}$ The study concluded that the pursuit of litigation precedes the development of psychological distress and not the reverse. ${ }^{46}$

In sum, the research suggests that while all litigants tend to experience strain, those with pre-existing cognitive, mental or emotional vulnerabilities can have those dispositions particularly exacerbated by litigation stress.

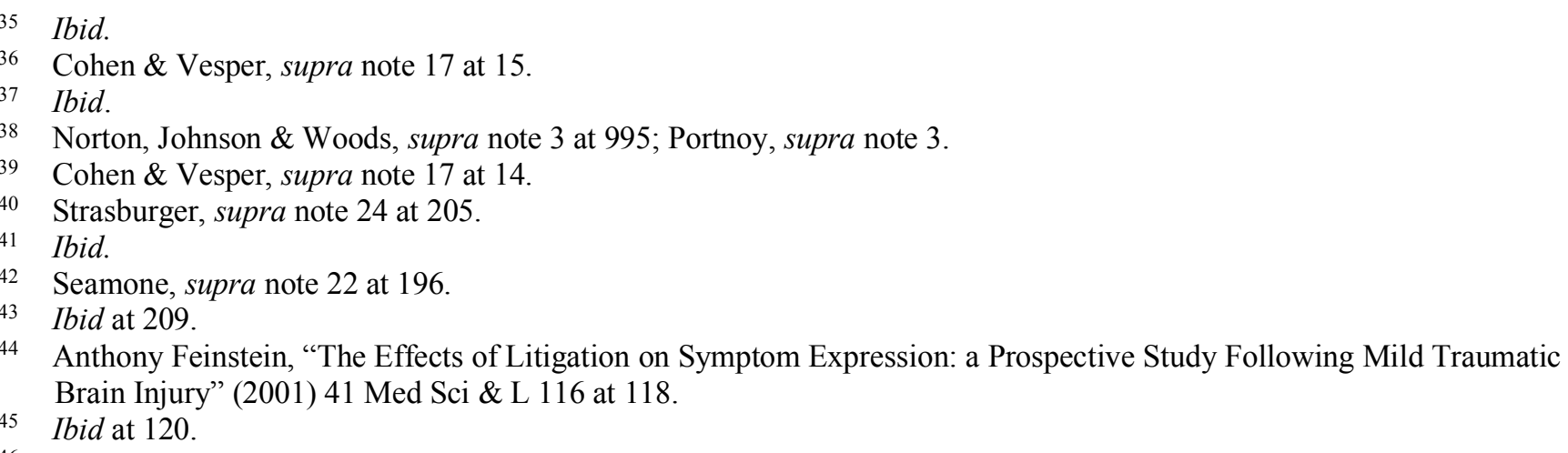




\section{B. Pain-Related Litigation}

Litigation is common for patients with pain disorders as the origin of the chronic pain is frequently related to injuries, accidents and negative medical outcomes. ${ }^{47}$ According to Marilyn Jacobs, pain disorders and ongoing litigation interact synergistically with one another. ${ }^{48}$ Pain-related litigants may be at risk for intensified symptom expression and inaccurate attribution of symptoms. ${ }^{49}$ Involvement in litigation is associated with increased pain, psychological distress and disability for chronic back pain patients. $^{50}$ Blake and Garrett speculate that ongoing litigation makes patients with chronic lower back pain less amenable to the restoration of function in their lives. ${ }^{51}$ Similarly, a study on patients with spinal disorders reveals that litigation is associated with both poorer function and greater pain. ${ }^{52}$

The emotional stress and turmoil of being subjected to legal scrutiny can intensify an underlying pain disorder. ${ }^{53}$ The validity of the pain complaints is often questioned or challenged, which may further damage the psyche of pain patients. ${ }^{54}$ Pain-related litigation is associated with increased depression, anger, frustration, anxiety, mistrust and despair. ${ }^{55}$ Litigants often lose motivation to engage in productive life activities. ${ }^{56}$

Litigation has also been linked with 'failed back syndrome', which is defined as "disabling back pain and/or sciatica of apparently disabling severity despite extensive therapy." $" 57$ A pending compensation claim has been identified as a risk factor for developing failed back syndrome. ${ }^{58}$ Involvement in litigation is thought to be a factor in the severity and duration of symptoms. ${ }^{59}$ When patients are facing pending litigation, it is rare for surgical interventions to result in lasting and significant improvement in symptoms and disabilities. ${ }^{60}$

While the relationship between mind and body is complex, the research shows that 'the experience of litigation' can complicate chronic pain conditions.

47 Marilyn S Jacobs, "Psychological Factors Influencing Chronic Pain and the Impact of Litigation" (2003) 1 Curr Phys Med Rehabil Rep 135 at 135.

48 Ibid.

49 Weissman, supra note 31 at 68.

50 PB Suter, The effect of employment and workers' compensation litigation on the pain, psychological state and disability of chronic back pain sufferers" (PhD Thesis, Edith Cowan University, Faculty of Commuinty Services, Education and Social Sciences, 1999) [unpublished].

51 C Blake \& M Garrett, "Quality of Life Outcomes in Patients with Chronic Low Back Pain” (1997) July-Sept IJMS 124 at 125.

52 Mark L Prasarn et al, "Negative effects of smoking, workers' compensation, and litigation on pain/disability scores for spine patients” (2012) 3(Suppl 5) Surg Neurol Int S366 at S367.

53 Jacobs, supra note 47 at 138.

54 Ibid at 138.

55 Ibid at 139.

56 Ibid.

57 JMS Pearce, “Aspects of the failed back syndrome: role of litigation” (2000) 38:2 Spinal Cord 63 at 63.

58 Ibid at 69.

59 Ibid at 66.

$60 \quad$ Ibid at 63. 


\section{Litigation Involving Sexual Assault and Sexual Harassment}

Civil actions for sexual assault have been described as offering multiple benefits to plaintiffs, with the caution that the emotional vulnerability of sexual assault victims may be exacerbated by the anxieties of litigation. ${ }^{61}$ Sexual assault claimants often enter the litigation process with an already undermined sense of safety, autonomy and self-worth. ${ }^{62}$ Many sexual assault victims decide to engage in civil litigation as a response to a crisis, such as a nervous breakdown or suicide attempt. ${ }^{63}$ The ordinary stress of litigation is magnified by the necessity of discussing a frightening and traumatic event as well as being forced to face the assailant in court. ${ }^{64}$ Women who engage in sexual assault litigation report poorer adjustment at work and at home. ${ }^{65}$

Lawson's research has also revealed that sexual harassment litigation does appear to exacerbate or perpetuate symptoms developed as a result of the original harassment. ${ }^{66}$ The physical symptoms related to sexual harassment include gastrointestinal disturbances, jaw tightness and teeth grinding, nervousness, binge eating, headaches, inability to sleep, tiredness, nausea, loss of appetite, weight loss, and crying spells. ${ }^{67}$ Sexual harassment litigation participation is associated with higher levels of PTSD symptoms, as well as lower levels of life satisfaction. ${ }^{68}$ Lawson describes the litigation itself as a "crisis event" which the plaintiff may not have the skills to manage. ${ }^{69}$ The plaintiff's psychological and emotional resources are being used to cope with the original harassment, the effects of which include anger, fear, depression, anxiety, irritability, lowered self-esteem, feelings of humiliation and alienation, as well as a sense of helplessness and vulnerability. ${ }^{70}$ A client already struggling with these emotions may be ill-equipped to take on the added burden of litigation stress. ${ }^{71}$ Women currently undergoing sexual harassment litigation exhibit demoralization, anxious arousal, fear and self-blame. ${ }^{72}$

While the pursuit of litigation can be motivated by important goals inside civil claims for sexual assault and harassment, the emotional (and therefore physical) strain of the process can extract a significant cost.

61 Nora West, "Rape in the Criminal Law and the Victim's Tort Alternative: A Feminist Analysis" (1992) 50 U Toronto Fac L Rev 96 at 116.

62 Ibid.

63 Bruce Feldthusen, Olena Hankivsky \& Lorraine Greaves, "Therapeutic Consequences of Civil Actions for Damages and Compensation Claims by Victims of Sexual Abuse" (2000) 12 Can J Women \& Law 65 at 79.

64 West, supra note 61 at 100.

65 Angela K Lawson, Having Your Day in Court: The Psychological Impact of Sexual Harassment Litigation (PhD Dissertation, University of Illinois at Urbana-Champaign, 2007) [unpublished] at 8.

66 Ibid at iv.

67 Louise F Fitzgerald, "Sexual Harassment and Social Justice: Reflections on the Distance Yet to Go" (2003) 58 American Psychologist 915 at 921.

68 Lawson, supra note 65 at 59.

$69 \quad$ Ibid at 15.

70 Fitzgerald, supra note 67 at 921.

71 Lawson, supra note 65 at 18.

72 Caroline Vaile Wright \& Louise F Fitzgerald, “Angry and Afraid: Women’s Appraisals of Sexual Harassment During Litigation" (2007) 31 Psychol Women Qt 73 at 81. 


\section{Divorcing Clients}

Research indicates that most adults manage the transition of divorce with resilience. ${ }^{73}$ However, for a small percentage of people, the acute stress of marital separation and divorce are associated with lasting decreases in psychological well-being. ${ }^{74}$ A transition out of marriage through separation or divorce increases psychological distress. ${ }^{75}$ Clients usually enter divorce litigation already feeling suspicious, hurt, frightened and confused. ${ }^{76}$ Due to the emotional issues and conflicts involved in marital breakdown, divorce proceedings have a substantial psychosocial impact on litigants. ${ }^{77}$ For many spouses, it can be a time of crisis, disorganization and vulnerability. ${ }^{78}$ Divorcing individuals attempt to deal with legal issues as they cope with a sense of failure, anxiety, depression, terror, anger, helplessness, hopelessness, lowered self-esteem and confusion. ${ }^{79}$ Spouses involved in high-conflict divorces are at a higher risk for severe psychopathology and substance abuse problems. ${ }^{80}$

Like the legal claims listed above, divorce proceedings occur at times of psychological disorientation and vulnerability for litigants - increasing the chance that the process itself can contribute to lingering psychological harm.

\section{E. Claims Involving Professional Negligence and Malpractice}

The psychological stakes can also be high on both sides of a medical malpractice - or other professional negligence - claim. ${ }^{81}$ Because plaintiffs are often dealing with loss, they may be subject to the kinds of vulnerabilities discussed above. Further, their needs for acknowledgment and accountability are often not met in litigation where defendants are attempting to preserve professional reputations, and insurers attempting to avoid admissions of wrongdoing. Surveys indicate that physicians perceive the process as arbitrary, unfair and adversarial. ${ }^{82}$ They tend to view lawsuits as random events over which they have no control. ${ }^{83}$ The longer the claim, the higher emotional costs associated with loss of reputation and the anxiety of an outstanding case. ${ }^{84}$ Because physicians perceive

73 David A Sbarra, "Divorce and Death: A Meta-Analysis and Research Agenda for Clinical, Social and Health Psychology" (2011) 6 Perspectives on Psychological Science 454 at 455; M Richards, "The effects of divorce and separation on mental health in a national UK birth cohort" (1997) 27 Psychol Med 1121 at 1121.

74 Sbarra, supra note 73 at 455; Richards, supra note 74 at 1121.

75 Lisa Strohschein et al, "Marital transitions and mental health: Are there gender differences in the short-term effects of marital status change?” (2005) 61 Soc Sci \& Med 2293 at 2299.

76 Bennett Wolfe, “The Best Interest of the Divorcing Family - Mediation Not Litigation” (1983) 29 Loy L Rev 55 at 72.

77 Ibid at 70 .

78 Ibid at 72.

79 Ibid.

80 Matthew Goodman et al, "Parent Psychoeducational Programs and Reducing the Negative Effects of Interparental Conflict Following Divorce” (2004) 42 Fam Ct Rev 263 at 266.

81 Zapzalka notes research links physician suicides to malpractice claims; Zapzalka, supra note 13 at 12.

82 Emily R Carrier et al, "Physicians' Fears of Malpractice Lawsuits Are Not Assuaged By Tort Reforms" (2010) 29 Health Affairs 1585 at 1591 .

83 Ibid.

84 Seth A Seabury et al, "On Average, Physicians Spend Nearly 11 Percent of Their 40-Year Careers with An Open Unresolved Malpractice Claim” (2013) 32 Health Affairs 111 at 116. 
the consequences of being sued as potentially disastrous to their medical reputation, psychological wellbeing and financial stability, the very possibility of a medical malpractice suit can trigger statistically irrational levels of risk aversion. ${ }^{85}$ High numbers of physician defendants note being affected psychologically and physically by litigation, ${ }^{86}$ and many experience shame through the process. ${ }^{87}$

Because of the personal losses at stake - which are high on both sides of professional negligence claims - this type of litigation can (like divorce) be psychologically painful for all parties.

\section{HOW IS LITIGATION STRESS MANIFESTED?}

Anxiety resulting from litigation can interfere with a client's daily mental, emotional and physical life. According to Cohen, lawsuits often trigger emotional reactions and disarrayed thinking in clients. ${ }^{88}$ For some clients, their interest narrows exclusively to things related to their case. ${ }^{89}$ Other litigants experience the opposite reaction of trying to avoid anything associated with the lawsuit. ${ }^{90}$ These clients will avoid conversations, people and activities in any way connected to their case. ${ }^{91}$ Many are haunted by memories of the investigative inquiries, dispositions and the experience of giving testimony. ${ }^{92}$ Anything related to the lawsuit in general, such as a television program or movie, can trigger thoughts about their own legal action, resulting in headaches, nausea, sweats, muscle tension and shakiness. ${ }^{93}$ For some clients, the agitation can become so severe that they experience panic attacks. ${ }^{94}$ Litigation-induced anxiety can interfere with daily functioning, as some clients experience difficulty with social situations, or going to work or school. ${ }^{95}$ Litigation stress can extend beyond waking hours, and cause problems such as sleeplessness and disrupted dreams. ${ }^{96}$ Lees-Haley also lists appetite disturbances, lowered selfesteem, disruptions of attention and concentration, indecisiveness, disruptions of sexual functioning, and feelings of hopelessness and pessimism as complaints associated with litigation stress. ${ }^{97}$ Other symptoms include anger, frustration, humiliation, indecision and despondency. ${ }^{98}$

Stress and its accompanying emotions may also impede decision-making about how or whether to proceed with litigation. "Strong emotions may cause decision makers to act impulsively, focusing on

85 Carrier et al, supra note 82 at 1591.

86 Zapzalka, supra note 13 at 12.

87 Theodore R LeBlang, “The Medical Malpractice Crisis-Is There a Solution?” (2006) 27:1 J Leg Medicine 1 at 11-12; Maxwell J Mehlman (2006), "The Shame of Medical Malpractice” 27:1 J Leg Medicine 17 at 24-27.

88 Cohen \& Vesper, supra note 17 at 16.

89 Ibid.

90 Ibid.

91 Ibid at 15.

92 Ibid at 16.

93 Ibid.

$94 \quad$ Ibid at 5.

95 Ibid at 16.

96 Ibid. at 5.

97 Lees-Haley, supra note 16 at 113.

98 Strasburger, supra note 24 at 204. 
short-term rather than longer-term goals".99 For example, studies by Huang and Wu show that certain emotional responses can increase the chances a client will choose to sue rather than settle. ${ }^{100}$ The emotions of anger and pride generally lead to a higher frequency of trials even when the case has a "non-positive expected wealth value" for the litigants. ${ }^{101}$ While people generally want to maximize their outcome, they are also motivated to make decisions that will protect their self-image, and the tension between these two motives can complicate decision-making. ${ }^{102}$ Other factors that interfere include mental depletion, ${ }^{103}$ and fight-or-flight reactions, ${ }^{104}$ in addition to the external influences of framing and anchoring. ${ }^{105}$ The quality of decisions decreases when clients are feeling mentally depleted. ${ }^{106}$ Brain functioning is said to require twenty percent of the body's total energy consumption, a much higher proportion of the body's energy resources as compared to other organs. ${ }^{107}$ The brain naturally shifts to an "autopilot", or sub-rational mode to conserve energy. ${ }^{108}$ This is especially likely to happen when a client is chronically emotionally and mentally exhausted. In the midst of this, cognitive "blind spots"109 are sure to affect decisions about whether to continue litigation, or not. ${ }^{110}$ Litigants may march forward, later finding themselves in the midst of a process with an unforeseen impact, or with an outcome they regret. $^{111}$

99 Jennifer K Robbennolt \& Jean R Sternlight, Psychology for Lawyers: Understanding the Human Factors in Negotiation, Litigation, and Decision-Making (Chicago: American Bar Association, 2012) at 46.

100 Peter H Huang \& Ho-Mou Wu, "Emotional Responses in Litigation" (1992) 12 Intl Rev L \& Econ 31 at 33; Chris Guthrie, "Better Settle Than Sorry: The Regret Aversion Theory of Litigation Behaviour" (1999) U Ill L Rev 43 at 83.

101 Huang \& Wu, supra note 100 at 33.

102 Richard P Larrick, "Motivational Factors in Decision Theories: The Role of Self-Protection: (1993) 113 Psychol Bull 440 at 444.

103 Nora Rock, "Putting Your Best Brain Forward: How neuroscience awareness and evolutionary psychology can help lawyers avoid claims and offer better client service" (2017) 16 LawPRO Mag 5 at 8; Shai Danziger et al, "Extraneous factors in judicial decisions" (2011) 108 Proceedings of the National Academy of Sciences of the United States of America 6889 at 6892.

104 Rock, supra note 103 at 7.

105 Daniel Kahneman, Thinking Fast and Slow (Canada: Doubleday Canada, 2011) at 88, 120.

106 Rock, supra note 103 at 8; Danziger et al, supra note 103 at 6892.

107 Rock, supra note 103 at 8.

108 Ibid.

109 Robbenolt \& Sternlight, supra note 99 at 26.

110 Noel Semple draws on some examples of this in his report, such as the paper's opening quote. Semple, supra note 2 at 639. See Andrew J Wistrich \& Jeffrey J Rachlinski, "How Lawyers’ Intuitions Prolong Litigation” (2013) 86:3 S Cal L Rev 571. See generally Kahneman, supra note 105; Thomas Gilovich, Dale Griffin \& Daniel Kahneman, eds, Heuristics and Biases: The Psychology of Intuitive Judgment (Cambridge, UK: Cambridge University Press, 2002); Randall L Kiser, Martin A Asher \& Blakeley B McShane, "Let's Not Make a Deal: An Empirical Study of Decision Making in Unsuccessful Settlement Negotiations" (2008) 5:3 J Empirical Leg Stud 551; Randall Kiser, Beyond Right and Wrong: The Power of Effective Decision Making for Attorneys and Clients (Berlin: Springer, 2010); Charles W Murdock \& Barry Sullivan, "What Kahneman Means for Lawyers: Some Reflections on Thinking Fast and Slow" (2013) 44 Loy U Chicago LJ 1377 at 1396; and Robbenolt \& Sternlight, supra note 99.

111 Guthrie, supra note 100 at 46. 
The legal process can also strain the litigant's relationships, causing the support systems of the litigant to "burn out." 112 Many litigants have a compulsive need to talk about the experience which exceeds the patience of their friends and family members. ${ }^{113}$ In this way, litigation can be a very isolating experience. Strasburger describes the embarrassment and humiliation of the lawsuit as having the potential to shrink the social world of the litigant. ${ }^{114}$ Ongoing litigation enables clients to put their lives on hold, and so avoid other aspects of their lives they do not want to deal with. ${ }^{115}$ Where the matter being litigated involves those familiar relationships - such as with a litigated divorce - the strain can be particularly intense. ${ }^{116}$ However, even where the matter being litigated is independent, families can experience considerable strain, with a discernable increase in disruptiveness, disorganization or incapacitation. ${ }^{117}$ The detailed review of the traumatic event itself, along with frequent discussions about the physical and psychological results of the ordeal can keep the family focused on the past, reaffirming disability and dysfunction while undermining attempts to move forward. ${ }^{118}$ The constant rehashing of the event can exacerbate flashbacks, nightmares and physical symptoms. The occurrence and nature of the litigation stress will be influenced by the intermingling of family characteristics, and litigation and lawyering styles. ${ }^{119}$

Some cases spread the impact of the strain beyond the individual experience to the community level. ${ }^{120}$ A study of the twenty years of litigation over the Exxon Valdez oil spill documented its tremendous toll on the communities and residents of Prince William Sound. ${ }^{121}$ The study identifies litigation as a 'secondary disaster' operating independently of other issues related to the spill, such as continuing ecological contamination and loss of fisheries resources. ${ }^{122}$ Lawsuits involving largescale technological disasters are especially stressful as they have the added complexity of scientific, factual information. ${ }^{123}$ Research reveals that the adversarial litigation contributed to the development of a "corrosive community", characterized by "a loss of trust in civic institutions, social isolation, group conflict, mental health problems, deteriorating social relationships and the emergence of "corrosive

112 Strasburger, supra note 24 at 204.

113 Ibid.

114 Ibid.

115 Ibid at 209.

116 Goodman et al, supra note 80 at 267.

117 Joyce H Vesper \& Larry J Cohen, "Litigating posttraumatic stress disorder: effects on the family" (1999) 27 J Psychiatry $\&$ L 313 at 315

118 Ibid at 316.

119 Ibid at 333.

120 Some have noted the social cost of anxiety over professional negligence litigation; Frank Furedi \& Jennie Bristow, The Social Cost of Litigation (Chichester: Centre for Policy Studies, 2012) at 3. This can be most pronounced among educators and health care providers: ibid, at 14-15; Adrian O'Dowd, "Doctors increasingly practice 'defensive medicine' for fear of litigation" (2015) 350 BMJ 87. Carrier et al, supra note 82 at 1585. Howard Minkoff, "Fear of Litigation and Cesarean Section Rates" (2012) 36 Semin Perinatol 390 at 390; JM Shwayder, "Liability in high-risk obstetrics” (2007) Obstet Gynecol Clin North Am 617.

121 J Steven Picou, "When the Solution Becomes the Problem: The Impacts of Adversarial Litigation on Survivors of the Exxon Valdez Oil Spill” (2009-2010) 7 U St Thomas L J 68 [Picou, “Exxon Valdez"] at 87.

122 Ibid at 82.

123 Picou, "Corrosive Community", supra note 21 at 1497. 
social styles' which perpetuate the continuous loss of community". ${ }^{124}$ The litigation was associated with damaged social relationships, increased conflict and serious mental health problems throughout affected communities. ${ }^{125}$ The litigation also destabilized the sense of community and trust in others among residents. ${ }^{126}$ The 2009 Supreme Court decision to reduce the punitive damage award has resulted in continuing social and psychological losses for the area. ${ }^{127}$ The authors of the study predict that community recovery may not occur during the lifetime of the plaintiffs. ${ }^{128}$ Shreve affirms that conflict over equitable damage payments, stress from protracted legal procedures and uncertainty about outcomes can undermine recovery in post-disaster communities. ${ }^{129}$

In several ways, litigation stress can interfere with the litigator's attempts to advance the substantive case. For example, litigation stress can impact the client's memory function. The vagaries of memory are well known, but stress hormones can have particular impact, impairing short-term memory - which explains why clients often have difficulty remembering issues they have already discussed with their lawyer. ${ }^{130}$ Stress also has the potential to distort memories, which can make it difficult for lawyers to distinguish between facts that are legally relevant from those that are not. ${ }^{131}$ The extreme stress and anxiety of feeling attacked under cross-examination can diminish a client's ability to function effectively as a witness. ${ }^{132}$ High cortisol levels can result in mental errors and impair a client's ability to remember and process information. ${ }^{133}$

Feelings of hopelessness and fear in the client can actually contaminate the results of a medical examination needed to help prove a client's injury claim. ${ }^{134}$ The stress of litigation can produce an intensified or distorted clinical presentation upon examination. ${ }^{135}$ This can result in incorrect diagnoses, as well as the misattribution of causation. ${ }^{136}$ False responses to questions can also arise if the client is second-guessing the evaluator or the significance of the questions being asked. ${ }^{137}$ For litigants experiencing pain due to injury, litigation adds stress and disruption to both the medical diagnosis and treatment. $^{138}$

124 Picou, "Exxon Valdez", supra note 121 at 79.

125 Ibid at 87.

126 Ibid.

127 Ibid.

128 Ibid.

129 Lewis Robert Shreve, "Lessons From Exxon-Valdez: Employing Market Forces to Minimize the Psychological Impact on Oil Spill Plaintiffs" (2011) 35 Law \& Psychol Rev 239 at 248. Picou recommends future research to examine how long-term litigation can create collective trauma within communities. Picou, "Exxon Valdez", supra note 121 at 1515. Rock, supra note 103 at 7; Winick, supra note 22 at 110.

131 Weissman, supra note 31 at 69.

132 Winick, supra note 22 at 110.

133 Ibid.

134 Cohen \& Vesper, supra note 17 at 11.

135 Weissman, supra note 31 at 68.

136 Ibid.

137 Cohen \& Vesper, supra note 17 at 11.

138 Jacobs, supra note 47 at 135. 
Where a client conveys emotional numbness or lack of affect, professionals evaluating the client may conclude he or she is not emotionally affected by their experiences. ${ }^{139}$ Under-estimating a client's distress can lead to a false diagnosis of "compensation neurosis", the tendency for symptoms to persist only as long as the potential for compensation continues. ${ }^{140}$ This misdiagnosis could in turn reduce the client's compensation claim. ${ }^{141}$ When a claimant has recovered from injury but then becomes worse after meeting with an attorney, it is often interpreted as malingering. However, the worsening symptoms could in fact be due to litigation stress. ${ }^{142}$ The difficulty in distinguishing litigation stress symptoms from complaints listed among damages can interfere with evaluations regarding the claim. ${ }^{143}$ Overlooking the impact of litigation stress on symptoms can result in incorrect psycholegal opinions. ${ }^{144}$ The failure to recognize the effects of litigation stress can also interfere with assessments of competency or fitness as a parent. ${ }^{145}$ When an expert witness is aware of litigation stress, he or she can better separate stresses from the original injury from those intrinsic to the litigation process. ${ }^{146}$

These manifestations of litigation stress can reach into the lawyer-client relationship and erode the client's trust. A client's dependency and vulnerability can enhance sensitivity to perceived slights. ${ }^{147}$ Even an unreturned phone call can erode the trust in the lawyer-client relationship. ${ }^{148}$ In exaggerated cases, clients may overreact to their attorney's mistakes. ${ }^{149}$

\section{WHAT ASPECTS OF THE LITIGATION PROCESS CAUSE STRESS?}

Although more research is needed, the following components of litigation have been noted as causing stress to litigants. The adversarial nature of the litigation process makes some level of stress inevitable. ${ }^{150}$ Much has been written about the way that adversarial processes complicate problemsolving, and sidetrack solutions which may have a more holistic or restorative impact. ${ }^{151}$ From a psychological standpoint, the process has been described as "noxious", ${ }^{152}$ creating a damaging "aura of combat"153 laden with complex concepts and unfamiliar language ${ }^{154}$ ("a game disconnected from the

139 Fulcher, supra note 13 at 82.

140 Elston, Bracy \& Koch, supra note 13 at 1147.

141 Ibid.

142 Lees-Haley, supra note 16 at 110.

143 Ibid.

144 Weissman, supra note 31 at 68.

145 Lees-Haley, supra note 16 at 110.

146 Gutheil et al, supra note 14 at 6.

147 Hickling et al, supra note 13 at 632.

148 Ibid.

149 Lees-Haley, supra note 16 at 113.

150 Feldthusen et al, supra note 63 at 115. Cohen \& Vesper, supra note 17 at 1; Lind et al, supra note 11 at 956.

151 Guiteil et al, supra note 14 at 11; Norton, Johnson \& Woods, supra note 3 at 995.

152 Ibid.

153 Strasburger, supra note 24 at 203.

154 Cohen \& Vesper, supra note 17 at 4; Lind et al, supra note 11 at 959. 
real world."155) Adversarial litigation may involve delay tactics in the hope that protracted litigation will wear the other party down. ${ }^{156}$ It provides only limited and scripted opportunities for litigant participation. ${ }^{157}$

Delay is identified as a major stressor in litigation. ${ }^{158}$ Clients enter the legal process with an expectation of the resolution of an important issue, and then are faced with delays associated with repeated scheduling changes, postponements and continuances. ${ }^{159}$ The delay can become agonizing as hope rises with each new scheduling date and then falls with each postponement. ${ }^{160}$ Some clients become emotionally numb in response to this cycle. ${ }^{161}$ The process can be tedious and overwhelming. ${ }^{162}$ Delay, alone, prevents clients from moving on psychologically and from developing a sense of "completion"163 or emotional closure. ${ }^{164}$ Delays in medical malpractice claims also present unique problems. An open claim may prevent physicians from learning from others' medical errors. ${ }^{165}$ The implementation of preventative quality and safety improvements can also be delayed. ${ }^{166}$ From the patient's standpoint, the length of the claim delays resolution and financial compensation. ${ }^{167}$ Patients are left waiting for the physician's acknowledgement of a potential medical error. ${ }^{168}$ The lack of physician responsiveness may contribute to a patient's decision to litigate. Evidence suggests that patients tend to prefer early apologies and are more likely to forgive physicians and forgo litigation when early disclosure occurs. ${ }^{169}$

Alternatively, for some clients the problem is not that the process is too slow, but rather too fast. A statute of limitations may actually push clients into litigation before they are psychologically ready to face the traumas involved with litigation. ${ }^{170}$ Litigation can then cause the recovery process to become disordered, as the client experiences developmental processes out of order from what is required for

\footnotetext{
155 Brent K Marshall, J Steven Picou \& Jan R Schlichtmann, “Technological Disasters, Litigation Stress, and the Use of Alternative Dispute Resolution Mechanisms” (2004) 26 Law \& Pol'y 289 at 295.

156 Ibid at 302.

157 Lind et al, supra note 11 at 959.

158 Elston, Bracy \& Koch, supra note 13 at 1146; O’Connell, supra note 4 at 339; Gutheil et al, supra note 14 at 11.

159 Ibid.

160 Ibid.

161 Ibid.

162 Vesper \& Cohen, supra note 117 at 334.

163 Elston, Bracy \& Koch, supra note 13 at 1146; Strasburger, supra note 24 at 205.

164 Gutheil et al, supra note 14 at 12. Especially true of wrongful death claims which can suspend the grief process, resulting in debilitating consequences for the claimant; Daniel W Shuman, "When Time Does Not Heal: Understanding the Importance of Avoiding Unnecessary Delay in the Resolution of Tort Cases" (2000) 6 Psychology, Public Policy and Law 880 at 890.

165 Seabury et al, supra note 84 at 116.

166 Ibid.

167 Ibid.

168 Ibid.

169 Ibid.

170 Gutheil et al, supra note 14 at 15.
} 
optimal healing. ${ }^{171}$ A traumatized client in the early stages of recovery will not be helped by being put on a "fast track" of accelerated court procedures. ${ }^{172}$

Whether too slow or too fast, the timing of the litigation processes is an example of one way in which clients cede control of the process to the legal system. This alone increases the risk of stress, since client perceptions of control have been identified as a key factor in their satisfaction or dissatisfaction with process. ${ }^{173}$ Winick stresses that exercising a degree of control and self-determination is important to psychological wellbeing. ${ }^{174}$ It is especially important for victims of legal wrongs. According to Herman, at the very time victims need to establish a sense of power and control over their lives, "the court requires them to submit to a complex set of rules and procedures they may not understand, and over which they have no control". ${ }^{175}$ The often intrusive nature of legal proceedings can make the litigant feel like the world is an unsafe place which can increase the need to regain a sense of control any way they can. ${ }^{176}$ Litigation also violates personal boundaries such as the need for privacy. ${ }^{177}$

As litigation progresses, even meetings with lawyers can be distressing, intimidating or disorienting for clients. ${ }^{178}$ So, too, with aspects of the building of the case (having to disclose information which a client knows can weaken their case, and produce information requested by the other side). ${ }^{179}$ The requirement for a plaintiff to prove injury can be a distinct source of distress, ${ }^{180}$ especially when the claim includes proof of emotional or psychological harm. ${ }^{181}$ Claims that require a client to re-tell her story several times also cause additional anxiety - where the repetition of interviews, and interview conditions, induce strain. ${ }^{182}$ Litigants may have to access traumatic memories, bringing up emotions and possibly activating dissociative defences. ${ }^{183}$

Examinations - at any point in the process - can be exhausting, stressful and disempowering for the client. ${ }^{184}$ For many, being placed under oath is a completely new experience that can be fraught with anxiety. ${ }^{185}$ Participants are also aware that their testimony can have a significant impact on others. ${ }^{186}$

171 Ibid.

172 Feldthusen et al, supra note 63 at 93.

173 Lind et al, supra note 11 at 958.

174 Winick, supra note 22 at 113.

175 Judith Lewis Herman, “The Mental Health of Crime Victims: Impact of Legal Intervention” (2003) 16 J of Traumatic Stress 159 at 159-160.

176 Strasburger, supra note 24 at 207.

177 Ibid.

178 Cohen \& Vesper, supra note 17 at 6 . As the case continues, the amount of time spent with attorneys has been identified as a specific type of litigation stress; Picou, "Corrosive Community", supra note 21 at 1497.

179 Cohen \& Vesper, supra note 17 at 9.

180 O'Connell, supra note 4 at 334.

181 Lawson \& Fitzgerald, "Sexual Harassment Litigation: A Road to Re-victimization or Recovery?” 9 Psychol Inj \& Law 216 at 217

182 Elston, Bracy \& Koch, supra note 13 at 1147; Fulcher, supra note 13 at 81; Vesper \& Cohen, supra note 117 at 333.

183 Fulcher, supra note 13 at 80 . Serious consequences can result from the sensitizing nature of the interview regime, which Fulcher calls "litigation-induced trauma sensitisation (LTS)"; Ibid at 82.

184 Dennis P Stolle \& Mark D Stuaan, "Defending Depositions in High-stakes Civil and Quasi-criminal Litigation: An Application of Therapeutic Jurisprudence" (2003) 4 West Crim Rev 134 at 134.

185 Cohen \& Vesper, supra note 17 at 10.

186 Stolle \& Stuaan, supra note 184 at 134. 
This, along with other personal circumstances or personality traits can place great pressure and stress upon the client. ${ }^{187}$ In preparing for examinations, a client may experience tension with his or her lawyer about how best to answer the questions. It is common for clients to feel intimated by the opposing lawyer. ${ }^{188}$ Having to answer questions in a particular format, as well as not being allowed to speak unless spoken to is typical, but can seem like a very unnatural form of communication for the litigant. ${ }^{189}$ Many litigants are frustrated at having to answer questions on demand while not being able to ask their own questions. ${ }^{190}$ Questions asked of the client can range from being vague and general to specific and probing. ${ }^{191}$ Strasburger compares the process to "being stripped naked". ${ }^{192}$ The client may be frustrated in having to answer questions which seem irrelevant or repetitive. ${ }^{193}$

Some questions may even seem insulting, especially if the client's truthfulness or integrity is being challenged. ${ }^{194}$ Many clients struggle daily with the consequences of the injury that led them to litigation in the first place. When their accounts of what happened are challenged it can exacerbate their loneliness, alienation and confusion, sometimes leaving them with a sense they are responsible for their own suffering. ${ }^{195}$ Other lawyer-client conflicts can spring from examinations as the client may feel the lawyer was not assertive enough on his or her behalf. ${ }^{196}$ Clients are affected by the tension between all parties in the room during such a process. ${ }^{197}$

Generally, psychologists warn that it is only therapeutic for a client to talk about trauma under controlled circumstances - that the courtroom "is not a substitute for the therapist's couch". ${ }^{198}$ It follows that examinations under oath are also linked with strain for the client. ${ }^{199}$ The extent of whether the retelling is healing or damaging depends not on the content of the story itself, but rather on the environment and the process of the re-telling. ${ }^{200}$ Questioning techniques often restrict litigants to respond to a set of yes or no questions, rather than constructing a coherent and meaningful narrative. ${ }^{201}$ The need to give testimony in a public trial has therefore been described as "exquisitely painful". ${ }^{202}$

187 Ibid at 134.

188 Cohen \& Vesper, supra note 17 at 10.

189 Ibid at 11.

190 Ibid.

191 Ibid at 10.

192 Strasburger, supra note 24 at 205.

193 Cohen \& Vesper, supra note 17 at 10; Winick, supra note 22 at 110.

194 Cohen \& Vesper, supra note 17 at 10; Strasburger, supra note 24 at 205; Weissman, supra note 31 at 69.

195 O’Connell, supra note 4 at 334.

196 Cohen \& Vesper, supra note 17 at 11.

197 Ibid.

198 David Mendeloff, "Trauma and Vengeance: Assessing the Psychological and Emotional Effects of Post-Conflict Justice" (2009) 31 Hum Rts Q 592 at 613. See also Brandon Hamber, "The Need for a Survivor-Centered Approach to the Truth and Reconciliation Commission" (1996) 9 Community Mediation Update 5. Although some counsel defendants to "tell their story' on their own terms, in a safe setting accompanying litigation: NA Ryll, "Living Through Litigation: Malpractice Stress Syndrome" (2015) 34:1 Journal of Radiology Nursing 35 at 35.

199 Stolle \& Stuaan, supra note 184 at 134.

200 Hamber, supra note 198 at 5.

201 Herman, supra note 175 at 159-160.

202 Strasburger, supra note 24 at 205. 
Testifying may increase traumatic responses, ${ }^{203}$ and litigants can feel helpless or frustrated as they are forced to listen to testimony (or arguments) which may sound unfavourable. ${ }^{204}$ Overall, a crucial factor in client perception of procedural fairness is whether or not they received dignified and respectful treatment during legal procedures. ${ }^{205}$ Regardless of the outcome, many litigants leave the process with what Strasburger terms a "bruised sense of personal integrity". ${ }^{206}$

\section{WHAT CAN LAWYERS DO TO MITIGATE THEIR CLIENTS' LITIGATION STRESS?}

Litigants experiencing stress do not have the necessary perspective to recognize these symptoms, or to distinguish them from other factors related to their case. ${ }^{207}$ Likewise, attorneys may observe stressrelated symptoms exhibited by their clients, but have no way to determine whether those symptoms are caused by the litigation process itself, or by other factors such as pre-existing conditions related to the litigation. ${ }^{208}$ Symptoms of litigation stress can be easily confused with conditions created by the original conflict or dispute. Furthermore, neither lawyers nor clients tend to be aware of how stress can contribute to clouded cognitive processes, and impaired decision-making during the litigation experience. ${ }^{209}$ By failing to recognize litigation stress, lawyers do not adequately prepare their clients for the emotional burdens of the litigation process itself, or even for the careful decision-making process that should be ahead of them. ${ }^{210}$

\section{A. Client Control - Information, Communication and Informed Decision-Making}

Clients generally find legal procedures more satisfying when they are involved in or feel some control of the process. ${ }^{211}$ According to Lenhart and Shrier, litigants who fare the best emotionally are those who set realistic goals, maintain a sense of control of the litigation process, seek out adequate support, appreciate and focus energy on restoring the original equilibrium of their lives and adequately acknowledge and grieve the losses that come with litigation, even when it has a favourable outcome. ${ }^{212}$ Diesen and Koch suggest that litigation stress can be reduced by lawyers providing a clearer

203 Mendeloff, supra note 198 at 613.

204 Cohen \& Vesper, supra note 17 at 13.

205 Lind et al, supra note 11 at 958; Winick, supra note 22 at 116; Lawson, supra note 65 at 18; Shuman, supra note 164 at 882.

206 Strasburger, supra note 24 at 207.

207 Cohen \& Vesper, supra note 17 at 1.

208 Ibid.

209 Wistrich \& Rachlinski, supra note 110. See generally Kahneman, supra note 105; Gilovich, Griffin \& Kahneman, supra note 110. U.S. empirical studies, comparing settlement offers to trial outcomes, show significant rates of decision error: Kiser, Asher \& McShane, supra note 110; Kiser, supra note 110. Lawyers are affected by cognitive biases as well as their clients: Murdock \& Sullivan, supra note 110 at 1396.

210 Gutheil et al, supra note 14 at 6.

211 Lind et al, supra note 11 at 961; Diesen \& Koch, supra note 4 at 24; Winick, supra note 22 at 115; Feldthusen et al, supra note 63 at 83.

212 SA Lenhart \& DK Shrier, "Potential costs and benefits of sexual harassment litigation" (1996) 26 Psychiatr Ann $132-$ 138. 
dissemination of information to claimants about the litigation process. ${ }^{213}$ Clients with little litigation experience can benefit from "surrogate knowledge" - information about how other people tend to experience an event. ${ }^{214}$

The conveyance of information by lawyers to their clients can be viewed as an educational process that may counteract feelings of loss of control. Clients with accurate information about the strengths and weaknesses of their case and a realistic assessment of the anticipated outcome and value of their case, are better equipped to make informed decisions. Client-decision-making is enhanced when counsel can engage in a focused dialogue about the client interests that can be served inside or outside the litigation process. Truly informed decision-making also requires clients to be equipped with clear and realistic predictions of the expected outcomes to be achieved from utilizing legal processes. This assessment of anticipated outcome must include a clear prediction of the anticipated financial value of the client's case, but also the social and psychological impact costs of litigation that may be experienced by the client in order to achieve the anticipated outcome. ${ }^{215}$

Open communication between the lawyer and client can enable a lawyer to understand their client and assess the impact of getting a trial outcome from the perspective of the client. Presenting information in concrete rather than abstract forms, breaking it into manageable segments, and using visual aids (flowcharts and decision trees) are all considered superior communication strategies. ${ }^{216}$ Such strategies are helpful in delivering information to clients, but also counteract cognitive biases normally at work in the human brain that cloud judgment. ${ }^{217}$ Clients with particular vulnerabilities may need a more targeted discussion of - and, if necessary, planning for - the litigation's 'psychological soft spots'. ${ }^{218}$ All of this is best advanced if the lawyer employs a client-centred approach (or a team mentality ${ }^{219}$ ), with a commitment to engaged and active listening. ${ }^{220}$

213 Diesen \& Koch, supra note 4 at 23.

214 Robbenolt \& Sternlight, supra note 99 at 99 . Diesen and Koch suggest that litigation stress can be reduced by lawyers providing a clearer dissemination of information to claimants about the litigation process; Diesen \& Koch, supra note 4 at 23.

215 For a review of risk assessment approaches and tools, see Heather Heavin \& Michaela Keet, "The Path of Lawyers: Enhancing Predictive Ability through Risk Assessment Methods" (Paper delivered at the Annual Conference of the Canadian Institute for Administrative Justive, Ottawa, 5-7 October 2016) online $<$ https://ciajicaj.ca/en/research/researchpapers $>$ / at 19-20. H Heavin \& M Keet, "Litigation Risk Analysis: Using Rigorous Projections to Encourage and Inform Settlement" Journal of Arbitration and Mediation, forthcoming, fall 2017; and H Heavin \& M Keet, "Reforming Fee Regimes And The Cost Of Civil Justice" in Trevor Farrow \& Les Jacobs eds., The Cost and Value of Justice (Vancouver: University of British Columbia Press, 2018)

216 Robbenolt \& Sternlight, supra note 99, see discussion at 166-169.

217 See supra 209 and accompanying text. Wistrich \& Rachlinski, supra note 110. See generally Kahneman, supra note 105; Gilovich, Griffin \& Kahneman, supra note 110. U.S. empirical studies, comparing settlement offers to trial outcomes, show significant rates of decision error: Kiser, Asher \& McShane, supra note 110; Kiser, supra note 110. Lawyers are affected by cognitive biases as well as their clients: Murdock \& Sullivan, supra note 110 at 1396.

218 Seamone, supra note 22 at 196; Fulcher, supra note 13 at 83; Diesen \& Koch, supra note 4 at 23.

219 Cohen \& Vesper, supra note 17 at 26.

220 Active listening occurs most effectively inside a relationship where trust and rapport exist, and where the focus is first on listening; See Robbenolt \& Sternlight, supra note 99 at 157-161, for discussion on how lawyer can build a foundation for effective communication. Active listening skills are linked with enhanced therapeutic benefits; Diesen \& Koch, supra note 4 at 24. The most effective exploration of psychological factors requires a balance of open and closed questions 


\section{B. Weighing Litigation and Considering Alternative Processes}

Strasburger recommends the lawyer and client attend to the risks and inevitable psychological stress of the legal process before the client commits to litigation. ${ }^{221} \mathrm{Wu}$ and Huang suggest it is possible to construct an economic model that allows for lapses, regret and psychological conflict involved in legal decision-making. ${ }^{222}$ Raising possible areas of impact, and even inviting the client to take some time to reflect or map out the pros and cons, ${ }^{223}$ will contribute to slow and systematic decision-making.

As part of this, lawyers are encouraged to discuss the full range of process alternatives with their clients. As an example, FitzGibbon has recommended mediation as an alternative to litigation to resolve sexual harassment claims, pointing out that the mediation process can be faster than litigation which allows recovery for the victim to begin sooner. ${ }^{224}$ She suggests that mediation can facilitate recovery by allowing the victim to be heard, understood and treated respectfully, and avoid the damaging dimensions of examinations and assessments of credibility that accompany litigation. ${ }^{225}$ Mediation can also protect privacy and allow the exploration of creative remedies. ${ }^{226}$ On the other hand, mediation and other consensus-based processes - especially in situations affected by coercion or the abuse of power carry significant risks. ${ }^{227}$ We are reminded that “... there is not one but multiple paths available to the claimant. Each path presents its own measures of costs and uncertainty in connecting the claimant to the desired outcome. Each path to justice, therefore, has a particular cost of access associated with it." ${ }^{228}$ A very complete risk analysis would consider projections and process costs - comparatively - taking several different justice paths into account in any given case.

\section{Monitoring for Stress and Decision Fatigue}

While informed decision-making by clients is fundamental to the lawyer-client relationship, it is important to monitor clients for "decision fatigue". ${ }^{229}$ Studies show that making repeated decisions

(Donald E Wiger \& Debra K Huntley, Essential of Interviewing (New York: John Wiley \& Sons, 2002) at 46) and "attending skills" (Rita Sommers-Flanagan \& John Sommers-Flanagan, Clinical Interviewing, 2nd ed (New York: John Wiley \& Sons, 1999) at 87).

221 Strasburger, supra note 24 at 204.

222 Huang \& Wu, supra note 100 at 42.

223 Tools exist in popular literature to help clients identify goals, and weigh priorities; see e.g. mind-maps ("How to do a Mind Map for Goal Setting", online: achieve-goal-setting-success.com <http://www.achieve-goal-settingsuccess.com/mind-map-for-goal-setting.html>); also see JS. Hammond, RL Keeney \& H Raiffa, Smart Choices: $A$ Practical Guide to Making Better Decisions (Boston, Massachusetts: Harvard Business School Press, 1999).

224 Susan A FitzGibbon, "Arbitration, Mediation and Sexual Harassment” (1999) 5 Psychol Pub Pol'y \& L 693 at 717.

225 Ibid at 718 .

226 Ibid.

227 See e.g. Echo A Rivera, Chris M Sullivan \& April M Zeoli, "Secondary Victimization of Abused Mothers by Family Court Mediators" (2012) 7:3 Feminist Criminology 234-52; Wanda Wiegers \& Michaela Keet, "Collaborative Family Law and Gender Inequalities: Balancing Risks and Opportunities" (2008) 46 Osgoode Hall LJ 733; and Linda C Neilson, “At Cliff's Edge: Judicial Dispute Resolution in Domestic Violence Cases" (2014) 52:3 Fam Ct Rev 529 at 537-39

228 Ali Assareh, "Forum Shopping and the Cost of Access to Justice: Cost and Certainty in International Commercial Litigation and Arbitration" (2012-2013) 31:1 JL \& Com 1 at 8-9. See also Semple, supra note 2 at 643.

229 Rock, supra note 103 at 8. 
depletes individuals' mental resources, making them more likely to decide in favor of the status-quo. ${ }^{230}$ Some lawyers will remind clients to eat foods high in protein and low in sugar when preparing for a negotiation or mediation, as these foods promote a slow and continual release of energy. ${ }^{231}$ Because stress and fatigue tend to result in more conservative choices it is necessary to allow clients sufficient time for important decisions. ${ }^{232}$ It is especially important to slow down the thinking process for clients when their understanding of legal concepts is limited. ${ }^{233}$ Therefore, scheduling multiple negotiation meetings is preferable to one single long meeting because the client will have time to reflect on various options. $^{234}$ Breaking up important processes is also an effective way to prevent regret. Clients often regret rushed decisions. ${ }^{235}$ When clients can move gradually in the direction of agreement they can better endorse what they are signing. ${ }^{236}$

Seamone recommends that lawyers regularly search for signals of impaired decision-making capacity and competence throughout the litigation process. ${ }^{237}$ Murdoch maintains that understanding how people think and how they can be persuaded is critical to the professional work of every lawyer. ${ }^{238}$ It is important to realize that many of the client's decisions are being made outside of his or her realm of awareness. Functional magnetic resonance imaging studies suggest that over $90 \%$ of our decisions are actually made subconsciously. ${ }^{239}$ The trauma of litigation can trigger reactions in the body that prompt a fight-or-flight reaction. ${ }^{240}$ This type of reaction can destabilize clients during times of important decision-making. ${ }^{241}$ A sign that a client may be in the midst of a fight-or-flight reaction is when he or she has a vacant expression during an intense consultation. ${ }^{242}$

\section{Advanced Planning and Collaboration with other Professionals}

If the litigation is proceeding, lawyers can prepare clients by educating them about potentially stressful information gathering or discovery processes and be assisted, where necessary, by professionals with appropriate interviewing or counselling skillsets. ${ }^{243}$ For example, where interviews are necessary as part of the collection and assessment of evidence, Fulcher recommends having an expert interviewer, trained in therapeutic counselling skills, perform the enquiry in such a way as to gather the necessary and sufficient data to meet the health and legal requirements for the case while simultaneously looking after the therapeutic needs of the victim/client. ${ }^{244}$ He also advises the interview be videotaped to limit

230 Danziger et al, supra note 103 at 6892.

231 Rock, supra note 103 at 8.

232 Ibid.

233 Ibid.

234 Ibid.

235 Ibid.

236 Ibid.

237 Seamone, supra note 22 at 210.

238 Murdock \& Sullivan, supra note 110 at 1399.

239 Rock, supra note 103 at 5.

240 Ibid at 7.

241 Ibid.

242 Ibid.

243 Canadian Bar Association, supra note 2 at 11-12 suggests that lawyers work with "Intermediaries" where appropriate.

244 Fulcher, supra note 13 at 83. 
the number of times the client needs to tell his or her story, as well as supplementing the initial interview with psychometric assessments such as questionnaires. ${ }^{245}$

If lawyers choose to conduct client interviews themselves, Diesen and Koch recommend the use of a structured interview that will gather relevant background information needed by all professionals involved. ${ }^{246}$ They also recommend reducing litigation stress by producing a typed chronology of medical attendance history so that medical history for accident-related problems is known to the experts prior to the assessments. ${ }^{247}$ A full description provided in the instruction letter could also reduce the number of times the client must discuss an accident. ${ }^{248}$

Mid-litigation examinations under oath may require extra preparation. The fear of presenting evidence under oath can be alleviated by making clients aware that the litigation process is an affective experience. ${ }^{249}$ Once aware of the emotional impact of testifying, the lawyer and client can then better plan the testimony. ${ }^{250}$ Winick also suggests attorney-client discussions and role-play exercises can be helpful in giving clients information control over the experience of providing testimony. ${ }^{251}$ Many lawyers do not engage in a follow-up discussion following the deposition, leaving the client feeling confused and uncomfortable. ${ }^{252}$ Stolle advises a post-deposition debrief in order to follow up with the client on any important legal points. ${ }^{253}$ A thoughtful debriefing session can also minimize any lingering anxiety over what the client has just experienced. ${ }^{254}$

Clients with vulnerabilities such as those identified above may need more time and information to identify the litigation's 'psychological soft spots.' Seamone recommends exploring the client's reactions to previews of the different phases of the litigation and then developing contingency plans. ${ }^{255}$ The lawyer should ask the client to consider how he or she may react to certain pieces of evidence or segments of testimony. ${ }^{256}$ With this knowledge, the lawyer can identify areas that need to be approached in a more cautious manner. ${ }^{257}$ A careful planning process for the litigation can prevent overwhelming reactions to triggers. ${ }^{258}$ It may be helpful to have someone from the client's support network attend important court dates. ${ }^{259}$

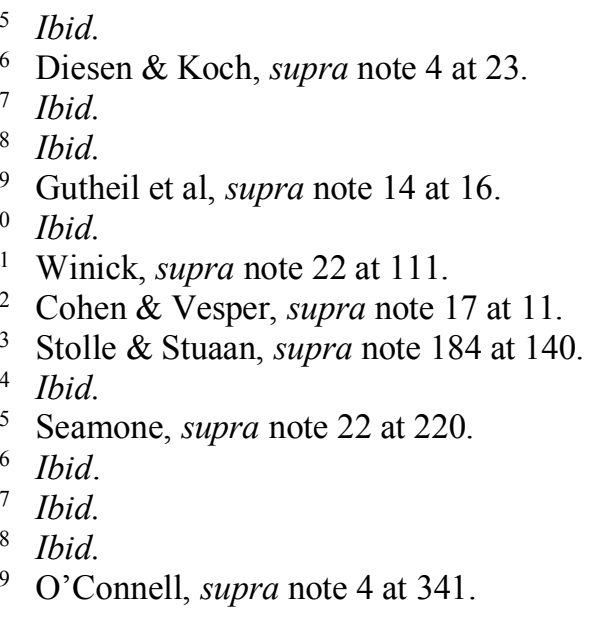


When working with families, the client-centred lawyer should monitor the family's response to the lawyer's involvement. ${ }^{260}$ With certain families, it may be helpful for the lawyer to communicate with a health care provider about the effects of litigation stress and how to deal with them. ${ }^{261}$

An attitude of professional collaboration could also encourage the lawyer to view the court system and judges in particular - as contributors to (rather than detractors from) such a thoughtful approach. For example, changes in civil court processes toward increased file management and settlement-oriented discussions enlarge the role of the judge in thoughtful litigation planning. ${ }^{262}$

\section{E. Lawyer Self-Care}

While being aware of the effects of litigation stress on clients, it is also important that lawyers be mindful of the stress they themselves experience. Lawyers are vulnerable to many psychological distresses, including compassion fatigue. ${ }^{263}$ As lawyers are exposed to the pain and distress suffered by their clients, there are cumulative psychological and physical effects often termed as "compassion fatigue" which results from having empathy for traumatized or suffering people. ${ }^{264}$ Over time, lawyers learn to subordinate their own emotional responses to the more objective needs of the client's case. ${ }^{265}$ Symptoms of compassion fatigue include cognitive effects such as lowered concentration; emotional effects such as guilt, anger and fear, as well as behavioural effects such as moodiness, appetite change and isolating oneself from others. ${ }^{266}$ Frequent exposure to traumatic information can also affect job performance, eventually leading to a reduced ability to communicate and work with colleagues. ${ }^{267} \mathrm{~A}$ lawyer's impaired ability can have adverse effects for the client, the public and the individual, ${ }^{268}$ in a profession that already struggles with statistically higher levels of depression, anxiety and stress. ${ }^{269}$ Lawyers may be more vulnerable to mental health issues because the very traits necessary to be a successful lawyer also have the potential to become psychological distresses. ${ }^{270}$ For example,

260 Vesper \& Cohen, supra note 117 at 333.

261 Ibid.

262 For example, see Louise \& Eric H Reiter, "Mediation by Judges: A New Phenomenon in the Transformation of Justice" (2006) 6:2 Pepp Disp Resol L J 351; Nicholas Bala, Rachel Birnbaum \& Justice Donna Martinson, "One Judge for One Family: Differentiated Case Management for Families in Continuing Conflict” (2010) 26:2 Can J Fam L 395; and Michaela Keet, "Informed Decision-Making in Judicial Mediation and the Assessment of Litigation Risk" J Arbitration \& Mediation [forthcoming, fall, 2017].

263 Norton, Johnson \& Woods, supra note 3 at 988.

264 Portnoy, supra note 3 at 48; Norton, Johnson \& Woods, supra note 3 at 989.

265 Ibid.

266 Portnoy, supra note 3 at 48.

267 Morgillo, supra note 3 at 457.

268 Laura Rothstein, "Law Students and Lawyers with Mental Health and Substance Abuse Problems: Protecting the Public and the Individual" (2007-2008) 69 U Pitt L Rev 531 at 533.

269 See Patrick J Schiltz, “On Being a Happy, Healthy, and Ethical Member of an Unhappy, Unhealthy, and Unethical Profession" (1999) 52 Vand L Rev 871 at 880; Patrick R Krill et al, "The Prevalence of Substance Use and Other Mental Health Concerns Among American Attorneys" (2016) 10 J Addict Med 46 at 51; Connie JA Beck, "Lawyer Distress: Alcohol-Related Problems and Other Psychological Concerns Among a Sample of Practicing Lawyers" (1996) 10 JL \& Health 1 at 10; Rothstein, supra note 268 at 532.

270 Beck, supra note 269 at 57; Martin EP Seligman, Paul R Verkuil \& Terry H Kang, "Why Lawyers are Unhappy" (2005) 10 Deakin L Rev 49 at 52; Todd David Peterson \& Elizabeth Waters Peterson, "Stemming the Tide of Law Student 
appropriately directed anger can help lawyers passionately represent a client's interests, yet can also be destructive when not properly managed. ${ }^{271}$

Although compassion fatigue is usually associated with social welfare and mental health professions, lawyers can be more susceptible to its effects. ${ }^{272}$ The legal profession is characterized by conditions that are inherently stressful. ${ }^{273}$ The lack of education and training providing protective factors from the adversarial nature of litigation is also a factor. ${ }^{274}$ While collaboration is encouraged in medical and mental health education, law schools tend to involve a more competitive model of instruction. ${ }^{275}$ The lack of consultation and cooperation can create a climate of isolation as lawyers are pressured to become self-reliant. ${ }^{276}$ Legal education rarely involves an interdisciplinary approach, leaving lawyers with little understanding about the effects of working with disenfranchised and traumatized populations. ${ }^{277}$ The requirement of client confidentiality also precludes the opportunity for lawyers to share their daily stresses with friends and family. ${ }^{278}$ Secondary traumatic stress, the stress resulting from helping a traumatized or suffering person, is also closely related to compassion fatigue. ${ }^{279}$ Secondary trauma can result in intensive imagery of the client's traumatic material as well as feelings of dread and horror. ${ }^{280}$

Attention to self-care is recognized as critical in ensuring that lawyers are able to manage stress and avoid the anxiety, depression and burn-out that may be experienced. Attention to these risks exists within the legal profession has resulted in the introduction of reflective practice and attention to self-care by both the professions and within law schools. ${ }^{281}$ There are also numerous professional development/on-line learning programs, supports and initiatives being promoted by legal and non-legal organizations. ${ }^{282}$ This shifts attention to developing positive physical and mental wellness behaviours, enabling lawyers to achieve the competencies necessary to assess the legal and psychological needs of their clients.

Depression: What Law Schools Need to Learn from the Science of Positive Psychology” (2009) 2 Yale J Health Pol'y, L \& Ethics 357 at 365.

271 Beck, supra note 269 at 57.

272 Norton, Johnson \& Woods, supra note 3 at 987.

273 Megan Seto, "Killing Ourselves: Depression as an Institutional, Workplace and Professionalism Problem" (2012) 2:2 online: UWO J Leg Stud 5<h p://ir.lib.uwo.ca/uwojls/vol2/iss2/5> at 6,7,8.

274 Norton, Johnson \& Woods, supra note 3 at 992.

275 Ibid at 993.

276 Ibid.

277 Ibid.

278 Ibid.

279 Morgillo, supra note 3 at 457.

280 Ibid at 458.

281 Michele Leering, "Conceptualizing Reflective Practice for Legal Professionals” (2014) 23 JL \& Soc Pol'y 83-106; Christine E Doucet, "Law Student, Heal Thyself: the Role and Responsibility of Clinical Education Programs in Promoting Self-Care" (2014) 23 JL \& Soc Pol’y 136-155.

282 The CBA has significant lawyer-wellness related programing and resources: See online: $<$ http://www.cba.org/CBAWellness/Home>; 


\section{CONCLUSION}

Awareness of the impact litigation processes can have on clients' mental and emotional health is important for the legal profession. The lawyer-client relationship is, necessarily, both professional and personal. However, lawyers vary widely in their ability to be emotionally supportive to clients. ${ }^{283}$ Understanding how to deal with the stress experienced by clients can result in better relations with - and better emotional outcomes for - clients. ${ }^{284}$ Fully informing clients of the impacts of litigation stress can better prepare the client to make decisions at the outset on the choice of process. Clients themselves are then better able to prepare themselves for the impact of litigation stress through planning necessary supports or counselling in advance of experiencing the stress. Alternatively, lawyers with knowledge of how legal processes can psychologically impact individuals can take proactive steps on behalf of the client to ensure that necessary supports are in place. Lawyers should also be able to recognise when a client is psychologically unable to assist them in providing direction regarding their claim, otherwise they can inadvertently increase the client's level of anxiety. ${ }^{285}$ Referring such a client for treatment when signs of stress have manifested themselves in the clients' behaviour can also reduce the likelihood of problems as the litigation progresses. ${ }^{286}$

Raising awareness within the legal profession of the psychological impact of litigation also opens up questions about responsibility of the profession to make systemic improvements that support client needs and thereby improve the quality of assessable justice. Litigation processes - which seek to resolve problems for clients - should not create new ones. Awareness of the impacts of litigation stress can provide an important impetus to better designed dispute resolution processes which focus on the needs of the ultimate user and (hopefully) beneficiary of the justice system. ${ }^{287}$

283 Strasburger, supra note 24 at 204.

284 Gutheil et al, supra note 14 at 6.

285 Cohen \& Vesper, supra note 17 at 14.

286 Gutheil et al, supra note 14 at 9.

287 Margaret Hagan, “Law By Design” (2014) online: <http://www.lawbydesign.co/en/home/>; Legal Design Lab, Stanford Law School, online: <http://www.legaltechdesign.com/>. 